US Army Corps

of Engineers ${ }_{\circledast}$

Engineer Research and

Development Center

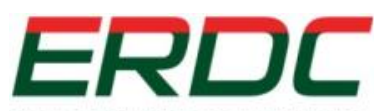

INNOVATIVE SOLUTIONS for a safer, better world

Wetlands Regulatory Assistance Program (WRAP)

\title{
Occurrence and Distribution of Ordinary High Water Mark (OHWM) Indicators in Non- Perennial Streams in the Western Mountains, Valleys, and Coast Region of the United States
}

Matthew K. Mersel, Robert W. Lichvar, Jennifer J. Gillrich, August 2014 and Lindsey E. Lefebvre

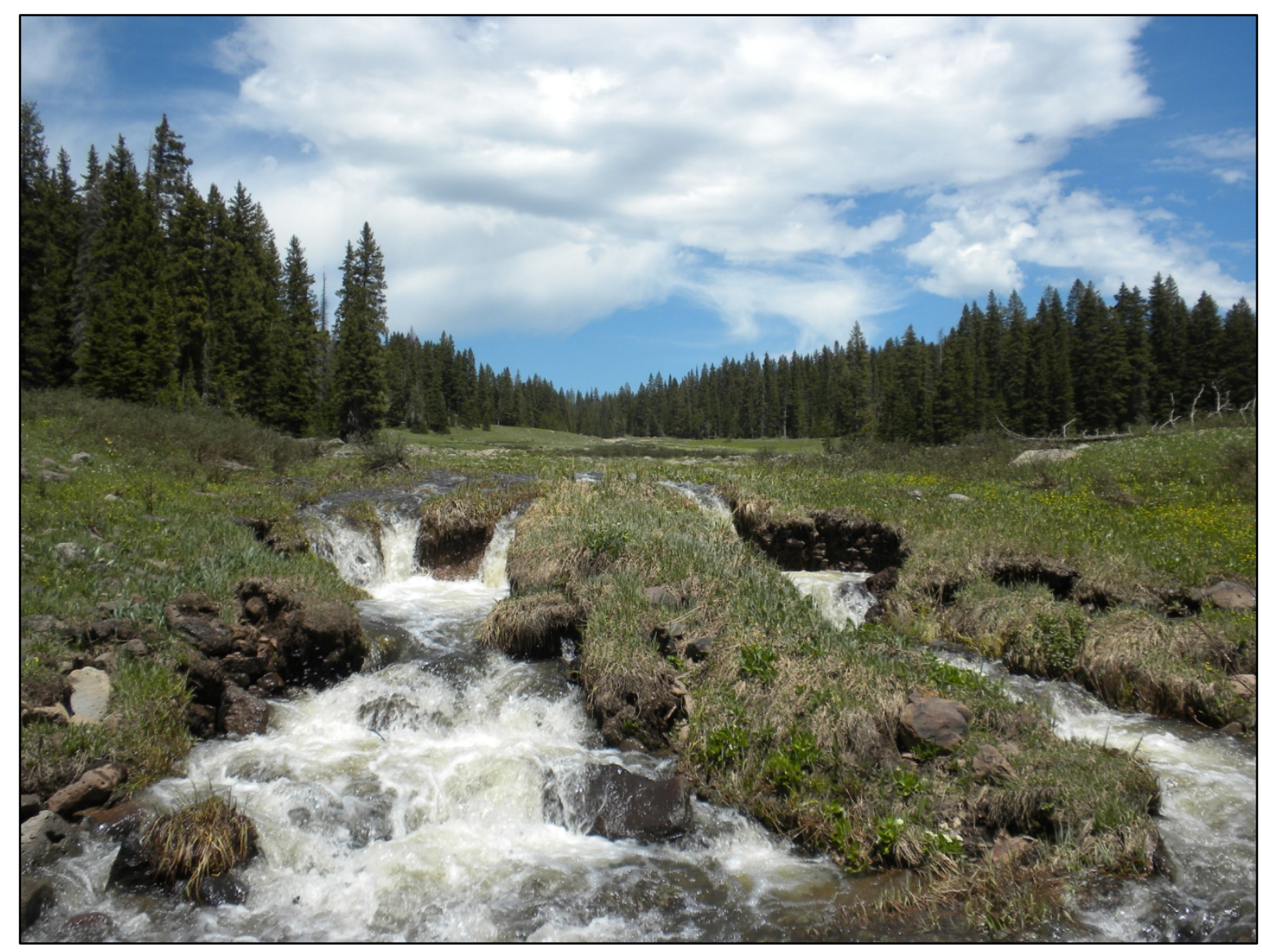


The U.S. Army Engineer Research and Development Center (ERDC) solves the nation's toughest engineering and environmental challenges. ERDC develops innovative solutions in civil and military engineering, geospatial sciences, water resources, and environmental sciences for the Army, the Department of Defense, civilian agencies, and our nation's public good. Find out more at www.erdc.usace.army.mil.

To search for other technical reports published by ERDC, visit the ERDC online library at http://acwc.sdp.sirsi.net/client/default. 


\section{Occurrence and Distribution of Ordinary High Water Mark (OHWM) Indicators in Non-Perennial Streams in the Western Mountains, Valleys, and Coast Region of the United States}

Matthew K. Mersel, Robert W. Lichvar, Jennifer J. Gillrich, and Lindsey E. Lefebvre

Cold Regions Research and Engineering Laboratory (CRREL)

U.S. Army Engineer Research and Development Center

72 Lyme Road

Hanover, NH 03755

Final Report

Approved for public release; distribution is unlimited.

Prepared for Wetlands Regulatory Assistance Program (WRAP)

U.S. Army Corps of Engineers

Vicksburg, MS 39180-6133 


\section{Abstract}

This study explored the occurrence and distribution of ordinary high water mark (OHWM) indicators in non-perennial streams in the Western Mountains, Valleys, and Coast (WMVC) Region of the United States. Physical and biological indicators of the OHWM were recorded and ranked (weak, moderate, or strong) at 150 ephemeral or intermittent stream sites sampled across the region. Three primary OHWM indicators-topographic break in slope, change in sediment characteristics, and change in vegetation characteristics - were found to be ubiquitous throughout the WMVC Region. At each stream sampled, a combination of at least two of these primary indicators was found to express a signature on the landscape, generally consistent with the lateral boundaries of the active channel. The distribution of the primary indicators and their rankings within the region showed no relationships to various climate, watershed, or channel characteristics examined using multivariate statistical analysis. This suggests the robust nature of these primary indicators and the active channel signature for delineating the OHWM in non-perennial streams throughout the WMVC Region. These findings support a more informed and consistent approach to OHWM delineation in the WMVC Region.

DISCLAIMER: The contents of this report are not to be used for advertising, publication, or promotional purposes. Citation of trade names does not constitute an official endorsement or approval of the use of such commercial products. All product names and trademarks cited are the property of their respective owners. The findings of this report are not to be construed as an official Department of the Army position unless so designated by other authorized documents. 


\section{Contents}

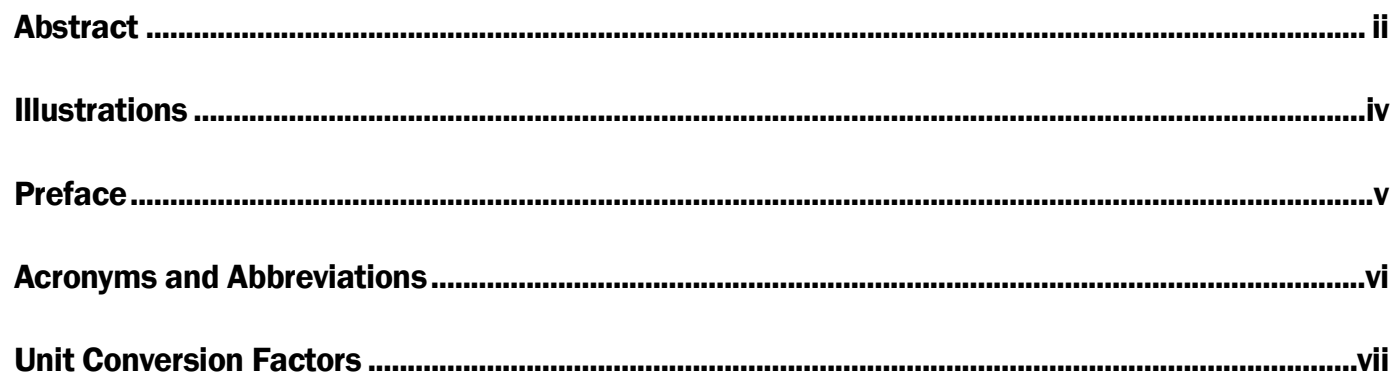

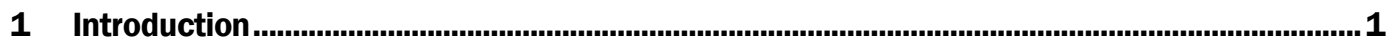

$1.1 \quad$ Understanding the OHWM ............................................................................. 3

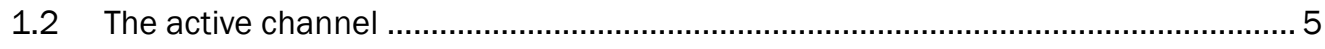

1.3 Study design overview ....................................................................................... 7

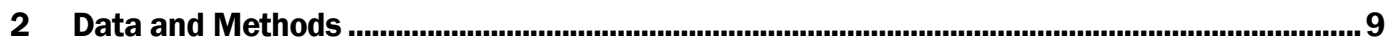

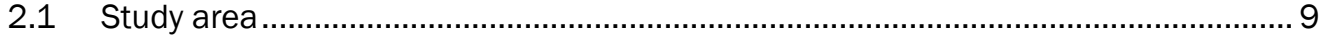

2.2 Sampling locations ........................................................................................ 10

2.3 OHWM delineation and data collection ............................................................... 10

2.4 Cross-sectional data ..................................................................................... 13

2.5 Watershed and climate data...................................................................... 14

2.6 Statistical methods................................................................................. 15

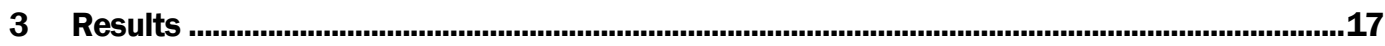

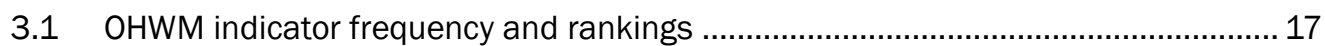

3.2 Ordination of sampled streams by using watershed and climate variables ............19

3.3 Ordination of sampled streams by using channel geometry variables ................... 21

4 Discussion and Conclusions ..............................................................................................24

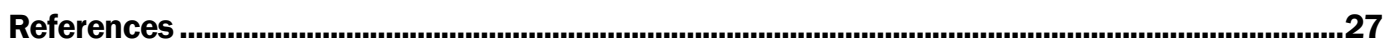

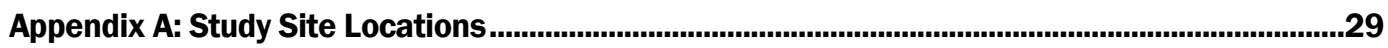

Report Documentation Page 


\section{Illustrations}

\section{Figures}

1 Common hydrogeomorphic units that form in stream systems in response to spatially and temporally varying hydrologic and geomorphic processes.

2 Map of the Western Mountains, Valleys, and Coast Region, data collection sites,

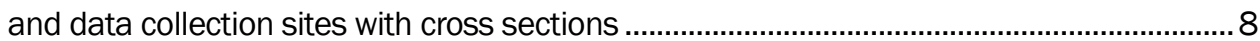

3 Examples of OHWMs delineated in non-perennial streams in the WMVC Region..............12

$4 \quad$ The distribution of rankings for each of the three primary indicators observed to correspond with the outer limits of the active channel, and thus with the OHWM, as recorded in 150 non-perennial streams sampled in the WMVC Region

5 The number of sample locations at which drift deposits were found below, at, and above the OHWM

6 NMDS ordination of 145 WMVC Region non-perennial streams based on watershed area, mean watershed elevation, mean annual precipitation, and mean annual SWE

7 Overlay of OHWM primary indicator rankings on an ordination of 145 WMVC Region non-perennial streams. The three primary indicators-break in slope, change in sediment characteristics, and change in vegetation characteristicsare ranked as either absent, weak, moderate, or strong for each stream sampled

8 NMDS ordination of 21 WMVC Region non-perennial streams by using four channel geometry variables-maximum channel width, maximum channel depth, width-to-depth ratio, and channel slope..

9 Overlay of OHWM primary indicator rankings on an ordination of 21 WMVC Region non-perennial streams. The three indicators-break in slope, change in sediment characteristics, and change in vegetation characteristics-are ranked as either absent, weak, moderate, or strong for each stream sampled.

\section{Tables}

1 Stream channel variables and their range of values among 21 sampled streams.

2 Watershed and climatic variables and their value ranges among 150 sampled streams.

3 Correlation coefficients of four variables with each axis in the ordination

4 Distribution of rankings for the three primary OHWM indicators among the five stream groups identified in an ordination of 145 streams.

5 Correlation coefficients of four stream channel variables with each axis in the ordination.

6 Distribution of rankings for the three primary OHWM indicators among the two stream groups identified in an ordination of 21 sampled streams. 


\section{Preface}

Support and funding for this project were provided by the U.S. Army Corps of Engineers (USACE) Headquarters through the Wetlands Regulatory Assistance Program (WRAP). The authors acknowledge and appreciate the interest and support of Margaret Gaffney-Smith and Karen Mulligan of the Headquarters Regulatory Program and Sally Yost of the U.S. Army Engineer Research and Development Center Environmental Laboratory (ERDC-EL).

This report was prepared by Matthew K. Mersel, Robert W. Lichvar, J ennifer J . Gillrich, and Lindsey E. Lefebvre (Remote Sensing/ GIS and Water Resources Branch, Timothy Pangburn, Chief), ERDC Cold Regions Research and Engineering Laboratory (CRREL). At the time of publication, Dr. J ustin Berman was Chief of the Research and Engineering Division. The Deputy Director of ERDC-CRREL was Dr. Lance Hansen, and the Director was Dr. Robert Davis.

Peer reviews and comments were provided by the following:

- Paul Anderson, Wetlands Specialist, Washington State Department of Ecology (WADOE)

- Ken Fritz, Research Ecologist, U.S. Environmental Protection Agency (EPA), Office of Research and Development

- J ohn Gartner, Research Physical Scientist, USACE CRREL

- Patricia Olson, Senior Hydrogeologist, WADOE

- J eanne Roningen, Research Physical Scientist, USACE CRREL

- Brian Topping, Environmental Protection Specialist, EPA, Wetlands Division

COLJ effrey R. Eckstein was the Commander of ERDC, and Dr. J effery P. Holland was the Director. 


\title{
Acronyms and Abbreviations
}

\author{
CRREL U.S. Army Cold Regions Research and Engineering Laboratory \\ CWA Clean Water Act \\ EL Environmental Laboratory \\ EPA U.S. Environmental Protection Agency \\ ERDC Engineer Research and Development Center \\ NMDS Nonmetric Multidimensional Scaling \\ OHWM Ordinary High Water Mark \\ GIS Geographic Information Systems \\ SNOTEL Natural Resource Conservation Service Snow Telemetry \\ SWE Snow Water Equivalent \\ USACE U.S. Army Corps of Engineers \\ USGS U.S. Geological Survey \\ WADOE Washington State Department of Ecology \\ WMVC Western Mountains, Valleys, and Coast \\ WRAP Wetlands Regulatory Assistance Program
}




\section{Unit Conversion Factors}

\begin{tabular}{|l|l|l|}
\hline Multiply & By & To Obtain \\
\hline degrees (angle) & 0.01745329 & radians \\
\hline inches & 0.0254 & meters \\
\hline
\end{tabular}




\section{Introduction}

Federal regulations define the ordinary high water mark (OHWM) as "that line on the shore established by the fluctuations of water and indicated by physical characteristics such as a clear, natural line impressed on the bank, shelving, changes in the character of soil, destruction of terrestrial vegetation, the presence of litter and debris, or other appropriate means that consider the characteristics of the surrounding areas" (U.S. Congress 1986). Under Section 404 of the Clean Water Act (CWA), the OHWM defines the lateral extent of federal jurisdiction in non-tidal waters of the United States in the absence of adjacent wetlands (U.S. Congress 1977). Thus, consistent, repeatable, and defensible OHWM delineation practices are essential for proper implementation of the CWA.

The dynamic nature of stream systems and fluvial processes can make accurate and consistent delineation of the OHWM difficult. Natural sources of variability in river and stream systems (e.g., climate, sediment supply, landscape position, etc.) are compounded by direct and indirect anthropogenic sources of variability (e.g., watershed alteration, dam emplacement and removal, climate change, etc.). Thus, it is challenging to impose a consistent measure of "ordinary" high flow conditions across systems in which the hydrology and geomorphology can vary greatly in both space and time.

OHWM delineation in non-perennial (i.e., intermittent and ephemeral) streams can be especially challenging. The U.S. Army Corps of Engineers (USACE) describes intermittent streams as having "flowing water during certain times of the year, when groundwater provides water for stream flow. During dry periods, intermittent streams may not have flowing water. Runoff from rainfall is a supplemental source of water for stream flow" (USACE 2012). Ephemeral streams have "flowing water only during, and for a short duration after, precipitation events in a typical year. Ephemeral stream beds are located above the water table year-round. Groundwater is not a source of water for the stream," and "[r] unoff from rainfall is the primary source of water for stream flow" (USACE 2012). In contrast to both intermittent and ephemeral streams, perennial streams have "flowing water year-round during a typical year. The water table is located above the stream bed for most of the year," and "[g]roundwater is the primary source of water for stream flow" (USACE 2012). 
Given the less persistent streamflow regimes characteristic of nonperennial streams, particularly ephemeral systems, the characterization of ordinary high water flows is perhaps more challenging than in perennially flowing streams. Moreover, depending on climate, vegetation, and other related factors, the appearance of some OHWM indicators may vary greatly between wet and dry seasons or between relatively infrequent flow events, more so than in many perennial streams. Mountainous terrain can present additional challenges to OHWM delineation. For instance, the relatively steep and confined valleys in which mountain streams commonly flow can restrict the development of some alluvial features (e.g., floodplains, bankfull benches, etc.) that are typical of low-gradient systems and that may help to identify the OHWM. Thus, in non-perennial mountain streams, it is often difficult to determine what constitutes ordinary high water and to interpret the physical and biological indicators established and maintained by ordinary high water flows.

Despite the legal and environmental importance of CWA implementation and the challenges of OHWM delineation in many fluvial systems, limited research has been performed or guidance produced concerning the OHWM and how to identify it in rivers and streams. Previous research related to OHWM identification in fluvial systems has focused primarily on arid ephemeral and intermittent stream systems, which dominate much of the southwestern U.S. Lichvar and Wakeley (2004) provided a comprehensive review of potential hydrologic, geomorphic, and vegetative indicators for use in OHWM delineations in arid streams and categorized their typical landscape positions with respect to the OHWM (above, at, or below). Lichvar et al. (2006) explored the distribution of six potential OHWM indicators (drift, litter, silt deposits, sand deposits, knick points, and mud cracks) within a reach of Mission Creek, CA, and found them to be randomly distributed throughout the study reach. This and other work by the U.S. Army Engineer Research and Development Center (ERDC) supported the development of A Field Guide to the Identification of the Ordinary High Water Mark (OHWM) in the Arid West Region of the Western United States (Lichvar and McColley 2008). Subsequent OHWM studies have continued to focus on arid systems (e.g., Lichvar et al. 2009; Curtis et al. 2011; Lefebvre et al. 2013a, 2013b) because of the unique regulatory challenges posed by the complex and dynamic fluvial forms and processes found in arid regions. Thus, while OHWM delineation practices in the Arid West Region have benefited greatly from these studies, how the 
OHWM and its physical indicators vary spatially and temporally in the rest of the United States remains largely unexplored.

Challenges and inconsistencies pertaining to OHWM delineation practices are becoming increasingly relevant in mountainous parts of the western U.S. in light of expanding development. This increased pressure on fluvial systems highlights the need for consistent, repeatable, and validated OHWM delineation practices in this region. These factors, combined with the particular challenges of OHWM delineation in non-perennial mountain streams, provided the motivation for this study.

\subsection{Understanding the OHWM}

The OHWM definition provided in the federal regulations leaves substantial room for interpretation. This is due in part to its necessary application to a wide variety of stream types (as well as lakes) in a wide variety of landscape settings, thus precluding a definition that is both universally applicable and highly specific. Therefore, OHWM delineations may depend on the investigator's interpretation of both the concept of the OHWM and the field indicators used to identify it. The following paragraphs are meant to increase clarity with regard to the underlying hydrologic and geomorphic concepts pertaining to the OHWM.

Federal regulations do not provide a strict hydrologic definition of the OHWM other than that it is "established by the fluctuations of water." Thus, the OHWM is not explicitly defined by or associated with a specific streamflow recurrence interval (e.g., the 2-year flood) or any other statistical measurement. Given the lack of direct hydrologic observations or measurements in most stream systems, a statistically-based definition would be exceedingly difficult and impractical to implement regardless. Therefore, the precise hydrologic frequency associated with the OHWM may vary between different streams or even between different locations along the same stream.

However, despite a vague hydrologic definition for the OHWM, some reasonable assumptions can be made regarding the hydrologic understanding of ordinary high water. Existing Corps regulatory guidance pertaining to the OHWM (USACE 2005) states that "[w] hen making OHWM determinations, districts should be careful to look at characteristics associated with ordinary high water events, which occur on a regular or frequent basis. Evidence resulting from extraordinary events, including major flooding and 
storm surges, is not indicative of the OHWM." Moreover, implicit in the term ordinary high water mark itself, the word ordinary can be taken to exclude extremes on either end of the streamflow spectrum (i.e., very low or very high flows) while the term high stands in contrast to low or moderate streamflow levels. Taken together, ordinary high water implies streamflow levels that are greater than average, but less than extreme, and that occur with some regularity. A common and reasonable interpretation of this concept, supported in part by legal precedent, is that ordinary high water refers to the ordinary or normal water levels that occur during the high water season (see Guest [1990] for some background information on the historical and legal basis for the OHWM). However, this reasoning only helps to narrow the concept of the OHWM, not to strictly define it.

In accordance with federal regulations (U.S. Congress 1986), the OHWM is instead defined by physical features (including vegetation and other biological indicators as opposed to a statistically derived point on the landscape that is not tied to physical evidence) that are proxies for the spatial extent of ordinary high water. Thus, the OHWM in most circumstances should correspond with physical evidence on the landscape. However, there is no ubiquitous mark or feature that represents exactly the same hydrologic frequency in all stream systems. Moreover, in many stream systems, there are multiple features or distinct points on the landscape that may meet the regulatory definition of the OHWM (i.e., more than one "line on the shore established by the fluctuations of water" [U.S. Congress 1986]). These features may be the remnants of a single flood event or repeated inundation; they may be established by low flows, high flows, or extreme flows. Additionally, while some features are regularly altered with each flow event (in terms of appearance or location), others are more stable over time. It follows that when using physical features to identify the extent of ordinary high water levels, the features themselves should be ordinary in the sense of being relatively stable and consistently present and identifiable over time. Thus, the OHWM pertains to those features evidenced to be established and maintained by high flows (i.e., above average but not extreme) that occur with some regularity and are therefore most associated with the concept of ordinary high water. It is useful, then, to consider that it is the mark on the landscape itself that is ordinary as shaped by high flows that occur with a frequency and power sufficient to establish and maintain a consistent mark on the landscape. 
The above reasoning helps to constrain the concept of the OHWM and the identification of field indicators for delineating the OHWM in rivers and streams. For instance, the locations of features known or evidenced to be representative of low, average, or extreme flow conditions or events can typically be rejected as potential OHWM locations. Likewise, features suggestive of individual flow events or those known or evidenced to be unstable or highly migratory over time are unlikely to accurately indicate the OHWM location. However, these constraints are secondary to the general requirement that the $\mathrm{OHWM}$ correspond with physical evidence that can be identified in the field, ideally using indicators that are relatively stable, both spatially and temporally.

\subsection{The active channel}

The term active channel, as it is used here, refers to that hydrogeomorphic unit of a stream system within which the local hydrologic regime and geomorphic processes are effective in maintaining a linear topographic depression or conduit on the land surface, typically characterized by the presence of a bed and banks. Hydrogeomorphic units are distinct macroscale geomorphic features formed within stream systems in response to spatially and temporally varying hydrologic and geomorphic processes. Figure 1 shows an idealized illustration of common hydrogeomorphic units (note that Figure 1 is more representative of low-gradient arid stream systems but is a good illustration of common alluvial surfaces and features and their typical spatial arrangements). Some hydrogeomorphic units (e.g., the active channel and floodplain) are common to many or most stream systems while others (e.g., low-flow and high-flow channels) are more common in particular regions or stream types. However, the active channel is the only hydrogeomorphic unit that is common to essentially every river or stream system as it is the active channel that effectively defines a river or stream as a feature on the landscape. The boundary of the active channel is also the stream feature that most closely meets the above criteria for the OHWM.

Following the concept of the effective discharge, the active channel is established and maintained by flows that occur with some regularity (typically on the order of several times per year to several times per decade) but not by very rare and extremely high flood events (Wolman and Miller, 1960). Thus, streamflow is generally confined within the active channel the vast majority of the time except during large flood events. The recurring flow levels associated with the effective discharge are thought to 
transport the most sediment over time and thus be most responsible for the average shape and size of the active channel. Therefore, the outer limits of the active channel are a reliable proxy for the spatial extent of channel-shaping flows that are above average, but less than extreme, and that occur with some regularity. This is in contrast to floodplains, which are generally inundated only infrequently during relatively large flood events, and less stable features, such as low-flow channels, drift deposits, matted vegetation, leaf clearing, and bank undercuts, which may be established by or shift in response to individual flow events or recent flow conditions. Thus, the active channel is that part of a stream system in which the majority of fluvial sediment transport processes occur and in which streamflow is fully contained except for during large flood events. The active channel can therefore be seen as ordinary with respect to the recurring high flows it contains and with respect to its ubiquity across the diversity of streams that exist in nature.

Figure 1. Common hydrogeomorphic units that form in stream systems in response to spatially and temporally varying hydrologic and geomorphic processes. Note that this is only a generalized model and that, as with most natural systems, a wide spectrum of possible geomorphic arrangements exists in stream systems. Substantial variability may exist between different streams and different locations along the same stream (adapted from Curtis et al. 2011).

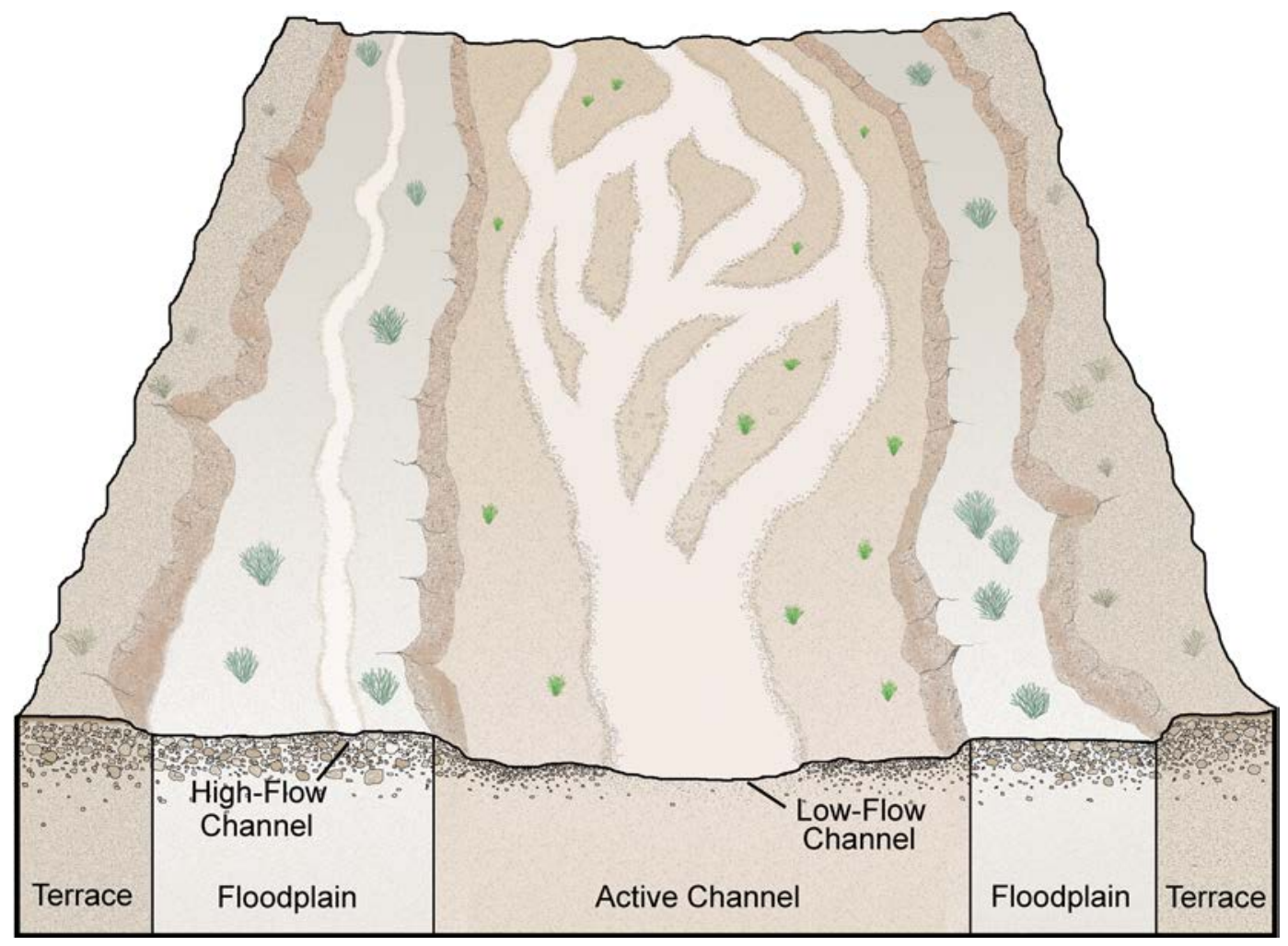


The association of the OHWM with the lateral extent of the active channel agrees well with the interpretation of ordinary high water and its intended limits. Moreover, this interpretation agrees well with previous OHWM investigations and delineation guidance in arid systems. Lichvar et al. (2006) found the active floodplain to be the most consistent and reliable feature with which to delineate the OHWM in Arid West non-perennial streams. The term active floodplain, as used in this prior study (as well as in the subsequent field manual [Lichvar and McColley 2008]) refers to the broader active zone within which a series of low-flow channels migrate-a braided channel arrangement that is common in dryland stream systems. The active channel, as described here and as pertains to single-thread (i.e., single channel) streams and streams in less arid regions, is analogous to the active floodplain as the term is used in previous investigations and OHWM delineation guidance for the Arid West. Therefore, in braided stream systems, the active channel, and thus the OHWM, may encompass multiple low-flow channels and the migratory islands that separate them.

\subsection{Study design overview}

This study explores the occurrence and distribution of OHWM indicators in non-perennial streams in the Western Mountains, Valleys, and Coast (WMVC) Region of the U.S. (Figure 2). The aims of this study are to (1) determine what are the most common and reliable OHWM indicators in WMVC non-perennial streams and (2) explore whether these indicators vary with regard to location, climate, or watershed and channel characteristics within the region. Physical and biological indicators of the OHWM were assessed, recorded, and ranked (weak, moderate, or strong) at 150 ephemeral or intermittent stream sites spread throughout the WMVC Region. Mean watershed elevation, watershed area, mean annual precipitation, and mean annual snow water equivalent data were acquired for each of these sites, and 66 cross sections were surveyed at 21 of the study sites to determine geomorphic characteristics of the sampled stream channels, such as width, depth, width- depth ratio, and slope. The study sites were then grouped based on common characteristics using ordination techniques and cluster analysis. Multivariate statistics were used to explore potential relationships between the frequency and strength of OHWM indicators and climate, watershed, and channel geometry characteristics. The preponderance, strength, and overall usefulness of various OHWM indicators are discussed along with suggestions for improving the standardization and repeatability of OHWM delineation practices in the WMVC Region. 
Figure 2. Map of the Western Mountains, Valleys, and Coast Region (purple), data collection sites (red), and data collection sites with cross sections (yellow).

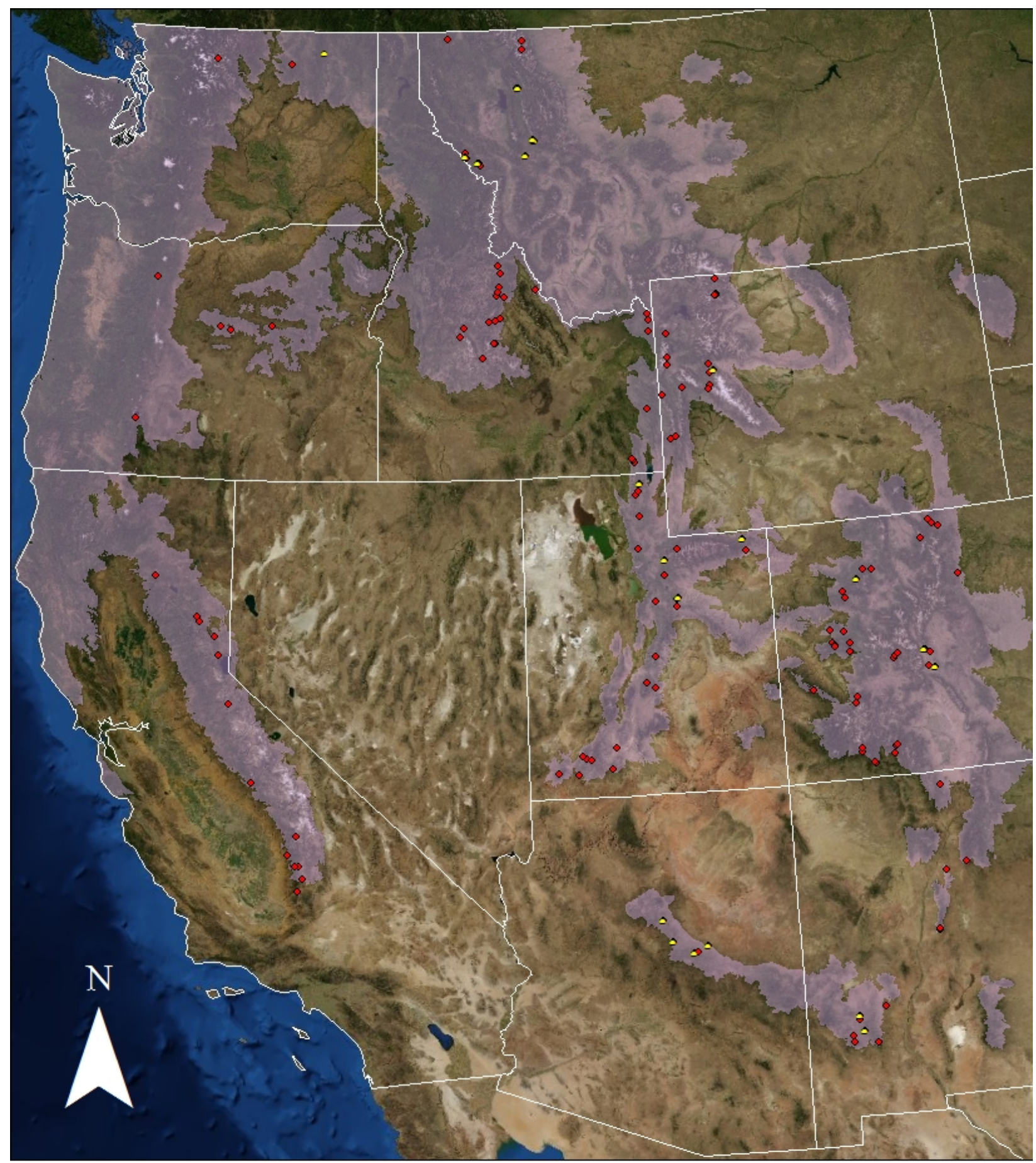

Western Mountains, Valleys and Coast Region

- Sample Points

= Cross-section Locations

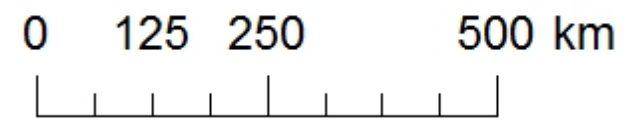




\section{Data and Methods}

\subsection{Study area}

The boundaries of the WMVC Region are the same as those used in the Regional Supplement to the Corps of Engineers Wetland Delineation Manual: Western Mountains, Valleys, and Coast Region (Version 2.0) (USACE 2010) (Figure 2). The following paragraphs, taken from USACE (2010), give a general description of the climatic and physiographic characteristics of the WMVC Region:

[T] he Western Mountains, Valleys, and Coast Region ... consists of portions of 12 states: Arizona, California, Colorado, Idaho, Montana, Nevada, New Mexico, Oregon, South Dakota, Utah, Washington, and Wyoming [Figure 2]. The region contains the major western mountain ranges-the Cascade Mountains, Sierra Nevada, and Rocky Mountains - and other scattered mountain ranges where the vegetation is dominated mainly by coniferous forests at lower elevations and alpine tundra at the highest elevations. The region also embraces the Willamette/ Puget lowlands, and the numerous valleys, meadows, high plateaus, and parks scattered within the mountainous areas that often support grasses, forbs, or shrubs, and includes the Coast Ranges, rain forests, and coastal zone from northern California to the Canadian border. About half of the region is in federal ownership, mostly in national forests. ...

The [WMVC] Region consists of steep, rugged mountains, high plateaus, gently sloping valleys, and a narrow coastal plain. Due to rugged topography, climatic conditions are highly variable across the region. The north- south orientation of the major mountain ranges forms barriers to the prevailing westerly winds, producing more abundant rainfall on west-facing slopes and rain-shadow effects on east-facing slopes and in interior valleys. Average annual precipitation ranges from more than 250 in. $(6,350 \mathrm{~mm})$ in the Olympic Mountains of Washington to $15 \mathrm{in}$. (380 mm) or less in the drier valleys and east-facing slopes of the Cascade Range and southern Rocky Mountains. Winters throughout the region tend to be long and cold, except near the ocean and in valleys west of the Cascades. The frost-free period is less than 70 days in the high 
mountains, but approaches 365 days on the coast (Bailey 1995; USDA Natural Resources Conservation Service 2006). This topographic and climatic diversity is reflected in very high vegetation diversity. Mountain slopes throughout the region generally are forested, but the dominant tree species change with location, elevation, and aspect. Other vegetation types include alpine tundra, mountain meadows, valley grasslands, shrublands, and hardwood riparian systems.

The [WMVC] Region surrounds and is interspersed with the Arid West Region . . . but generally receives more abundant rainfall and/ or snow, has lower average temperatures, higher humidity, and lower evapotranspiration rates. . . Many of the major streams and rivers that flow into and through the Arid West have their headwaters in the [WMVC] Region. ... [A]lthough no one environmental characteristic is diagnostic . . . [i]n many areas of the West, the transition between the two regions is indicated by the upper limit of pinyon/juniper and associated shrub dominated communities, and the lower limit of ponderosa pine or other coniferous forests.

\subsection{Sampling locations}

150 non-perennial stream systems were sampled throughout the WMVC Region (Figure 2) during late spring and summer of 2010 and summer and early fall of 2011. The chosen sites capture much of the climatic and physiographic variability within the region. These included locations in 10 states-Arizona, California, Colorado, Idaho, Montana, New Mexico, Oregon, Utah, Washington, and Wyoming. Practical limitations prevented sampling in all parts of the WMVC Region, and some areas contain few or no sample points (e.g., the Pacific coastal mountain ranges and some of the smaller ranges scattered throughout the region). For the purposes of this study, no distinction was made between intermittent and ephemeral streams. Most streams were dry at the time of sampling, and all sampled streams were hydrologically unregulated and minimally disturbed.

\subsection{OHWM delineation and data collection}

The OHWM delineation approach used in this study was based on interpretation of federal regulations and regulatory guidance (as discussed in Section 1.1), extensive experience with OHWM delineations in this region and elsewhere, and an aim for consistency and repeatability in OHWM de- 
lineation practices. Delineations relied solely on field evaluation of physi$\mathrm{cal}$ and biological features and the preponderance of evidence present at the time of each site visit. At each site, the OHWM was assessed along a representative and fairly homogenous stream reach, the length of which varied depending on site conditions. Figure 3 shows several examples of OHWMs delineated in the WMVC Region.

Based on the reasoning discussed in Section 1.1, for the purposes of this study, the OHWM was generally assumed to correspond with the outer limits of the active channel. Additionally, emphasis was placed on using indicators thought to be relatively stable (i.e., continually present and identifiable) over time and on identifying multiple (i.e., at least two) OHWM indicators at each site. To meet these criteria, delineation relied heavily on identifying macro-scale geomorphic features, namely lateral topographic breaks in slope. Where only one lateral break in slope was identified for a given stream reach, it was generally assumed to be the top and outer extent of the active channel banks and thus the location of the OHWM. Based on the observed angle of topographic change, each break in slope was ranked and recorded as either weak $\left(<30^{\circ}\right)$, moderate $\left(30^{\circ}-\right.$ $\left.60^{\circ}\right)$, or strong $\left(>60^{\circ}\right)$. Where multiple lateral breaks in slope were identified for a given stream reach, additional features, namely sediment and vegetation characteristics, were relied upon to determine which topographic change was most reasonably associated with the active channel limits. This typically was the location (perpendicular to the principle direction of streamflow) with the strongest or greatest number of physical or biological indicators.

Additional features corresponding with active channel boundaries or indicating the outer limits of the active channel were also recorded and ranked as weak, moderate, or strong at each site. These rankings did not typically follow strict quantitative criteria as for break in slope. Instead, these qualitative rankings, which allowed for rapid collection of summary data, captured the degree to which each indicator was defined on the landscape (i.e., distinct vs. gradual) and was generally useful for identifying the location of the OHWM at each stream site. At each location sampled, these rankings were determined by consensus among the same investigators so as to maintain consistency throughout the study. 
Figure 3. Examples of OHWMs delineated in non-perennial streams in the WMVC Region. The approximate OHWM locations are indicated by dashed lines.

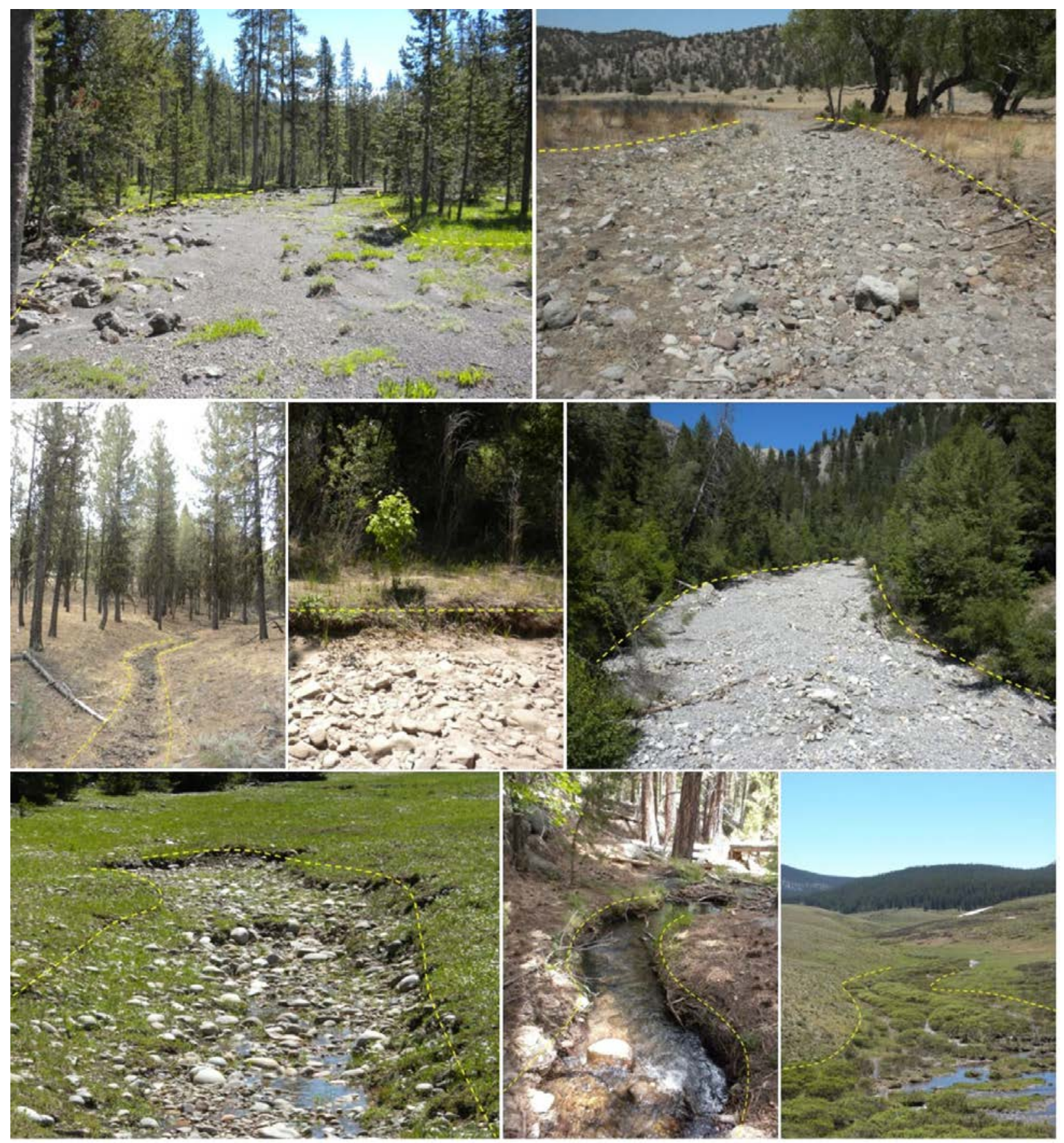

In addition to the above sampling approach, extra data were collected regarding the occurrence of drift deposits and their location with respect to the OHWM. Drift (also termed wrack) refers to organic and other material that is deposited as water recedes, often during flood events. Drift commonly forms linear features or piles and is often found on the upstream side of previously inundated vegetation and other barriers that trap debris. 
These extra data were collected because of the reference to "the presence of litter and debris" as a potential OHWM indicator in federal regulations (U.S. Congress 1986) and the knowledge that these features are commonly used to identify the OHWM in stream systems. At each site, any drift deposits present were recorded as being located above, at, or below the OHWM. Where multiple drift deposits were found along a given stream transect (i.e., deposits evidenced to represent different flow events), the relative location of each was recorded separately.

\subsection{Cross-sectional data}

A total of 66 cross sections were recorded at 21 of the stream sites sampled (Figure 2; Table A1). At each of these sites, either three or four cross sections were surveyed; and spacing between the cross sections was typically on the order of 15 to $30 \mathrm{~m}$. Cross sections were spaced so as to capture the variability in stream features along a short stream reach. The positions of physical and biological features, the OHWM, and any other notable features of interest were recorded along each cross section.

Physical stream channel dimensions were calculated from the surveyed cross sections. Four quantitative variables-maximum channel width, maximum channel depth, width-to-depth ratio, and channel slope-were calculated for each of the 66 cross sections. Maximum channel width was calculated as the horizontal distance between the top of the left and right banks. In the case of multi-threaded channels, maximum channel width was calculated for each flow path; and the widths of the individual flow paths were summed. Maximum channel depth was calculated as the difference in height between the top of the lowest bank and the deepest point in the cross section. To reduce small-scale spatial variability and to get a summary value for each stream, maximum channel width and depth were averaged at each stream from the three or four cross sections surveyed. Width-to-depth ratio was calculated as the maximum channel width divided by maximum channel depth. Channel slope was calculated as the difference in the minimum channel elevations between the farthest downstream and the farthest upstream cross sections divided by the horizontal distance between the two cross sections. Table 1 gives a summary of these data and the range of values among the 21 stream sites for each of these four variables. 
Table 1. Stream channel variables and their range of values among 21 sampled streams.

\begin{tabular}{|l|c|}
\hline Variable & Values \\
\hline Maximum channel width & $0.9-16.3 \mathrm{~m}$ \\
\hline Maximum channel depth & $0.1-1.6 \mathrm{~m}$ \\
\hline Width-to-depth ratio & $3.6-70.9$ \\
\hline Channel slope & $0.1-0.41$ \\
\hline
\end{tabular}

\subsection{Watershed and climate data}

For each sample location, four quantitative variables-watershed area, mean watershed elevation, mean annual precipitation, and mean annual snow water equivalent (SWE) - were collected from a variety of existing datasets. Table 2 gives the ranges of the acquired data.

Table 2. Watershed and climatic variables and their value ranges among 150 sampled streams.

\begin{tabular}{|l|c|}
\hline Variable & Values \\
\hline Watershed area & $0.03-2.71 \mathrm{~km}^{2}$ \\
\hline $\begin{array}{l}\text { Mean watershed } \\
\text { elevation }\end{array}$ & $1182.6-3566.2 \mathrm{~m}$ \\
\hline $\begin{array}{l}\text { Mean annual } \\
\text { precipitation }\end{array}$ & $26.1-174.8 \mathrm{~cm}$ \\
\hline Mean annual SWE & $0-740.4 \mathrm{~cm}$ \\
\hline
\end{tabular}

StreamStats, a web-based geographic information system produced by the U.S. Geological Survey (USGS) (https://water.usgs.gov/osw/streamstats/), was used to extract watershed area, mean watershed elevation, and mean annual precipitation for those sampling locations for which these data were available (those in California, Colorado, Oregon, and Washington). Where StreamStats data were not available (those locations in Arizona, Idaho, Montana, New Mexico, Utah, and Wyoming), a 10 m USGS digital elevation model and ArcMap 10.0 Spatial Analyst tools were used to delineate watershed boundaries and to calculate watershed area and mean watershed elevation. Mean annual precipitation at these locations was extracted from an Oregon Climate Service precipitation shapefile downloaded from the U.S. Department of Agriculture Geospatial Data Gateway (http://datagateway.nrcs.usda.gov/). For each sampling site, mean annual SWE was taken from the nearest sampling site in the Natural Resource Conservation Service Snow Telemetry (SNOTEL) dataset

(http://www.wcc.nrcs.usda.gov/snow/sweavg.html). Given the relatively sparse spacing 
of SNOTEL sites, these values serve as only a first order characterization of mean annual SWE at any given site.

\subsection{Statistical methods}

The collected data were analyzed with nonmetric multidimensional scaling (NMDS) ordination techniques, cluster analysis, and discriminant analysis using PC-ORD 5.33 software (McCune and Mefford 2006). Ordination is a multivariate technique used to examine relationships among sample units and to explore variables that may be associated with these patterns. Two ordinations of the sampled streams were performed using two different sets of variables.

The first ordination used four watershed and climatic variableswatershed area, mean watershed elevation, mean annual precipitation, and mean annual SWE-to position all 150 stream sites along three axes (three axes were sufficient to explain most [96.7\%] of the variation in the data). Pearson correlation coefficients suggested that none of the variables were auto-correlated $(\mathrm{r} \leq 0.46)$. The data were monotonically transformed and normalized by their standard deviations so that no variable would exert excessive influence on the analysis (McCune and Grace 2002).

The second ordination used four channel-geometry variables-maximum channel width, maximum channel depth, width-to-depth ratio, and channel slope-to position 21 stream sites along two axes (two axes were sufficient to explain most [97.3\%] of the variation in the data). Pearson correlation coefficients suggested that these variables were not auto-correlated $(\mathrm{r} \leq \mathrm{0.55})$. The data were monotonically transformed to improve normality (McCune and Grace 2002).

Cluster analysis was used to group the stream sites in each ordination. Groups of channels were sequentially merged based on similarities in the variables by which they were sorted. With increasing group size, the resulting groups became more heterogeneous; and information about the differences among channels was lost. Discriminant analysis was used to determine if the cluster analysis misclassified any of the streams and whether the groups of sampled streams were significantly different from one another.

OHWM indicator rankings (absent, weak, moderate, strong) for each stream site were superimposed (i.e., the streams were colored by ranking 
for visual comparison) over the ordinations to explore relationships between the frequency and strength of OHWM indicators and the climate, watershed, and channel characteristics associated with those streams. Monte Carlo tests, $\mathrm{R}^{2}$ values, stress, and stability were used to evaluate the solutions. The $\mathrm{p}$-value from each Monte Carlo test indicated whether or not the solution was stronger than expected by chance. The $\mathrm{R}^{2}$ value described the percentage of variation in the physical dimension data explained by the ordination diagram. Stress, a numerical value that ranges from 2.5 to 40, describes the amount of difficulty NMDS has in converting a data point's position in the multi-dimensional environment to its new position in two- or three-dimensional ordination space. Stress generally increases as the number of sample units and the number of points in a data matrix increases. Stress levels of 5- 10 indicate that the ordination is sound and there is little risk of misinterpreting the solution. Stress levels near 20 indicate that the solution could be misleading. When stress is 20 or greater, the ordination is considered so inaccurate that it is unusable (McCune and Grace 2002). To ensure that it has found the solution with the least stress, NMDS shifts the position of sample units numerous times and re-evaluates stress. These shifts are called iterations. Stability was evaluated by examining a graph illustrating stress values over the course of 250 iterations. Stable solutions produce graphs that decrease quickly and level off smoothly (McCune and Grace 2002). 


\section{Results}

\subsection{OHWM indicator frequency and rankings}

This study found several physical or biological features that consistently correspond with the outer limits of the active channel, and thus with the location of the OHWM, in non-perennial streams throughout the WMVC Region. For the sake of description and analysis, these features were grouped into three OHWM indicator categories (herein referred to as primary indicators):

1. Break in slope - any notable change in the topographic gradient perpendicular to the principle direction of streamflow

2. Change in sediment characteristics - any transition in the degree of soil development or the size, shape, or other physical qualities of sediment perpendicular to the principle direction of streamflow

3. Change in vegetation characteristics-any transition in the density, growth form stage, or species composition of vegetation perpendicular to the principle direction of streamflow

Figure 4 summarizes the frequency of occurrence and rankings (weak, moderate, or strong) for each of these three primary OHWM indicators among the 150 sampled streams.

Figure 4. The distribution of rankings for each of the three primary indicators (break in slope, change in vegetation characteristics, and change in sediment characteristics) observed to correspond with the outer limits of the active channel, and thus with the OHWM, as recorded in 150 non-perennial streams sampled in the WMVC Region.

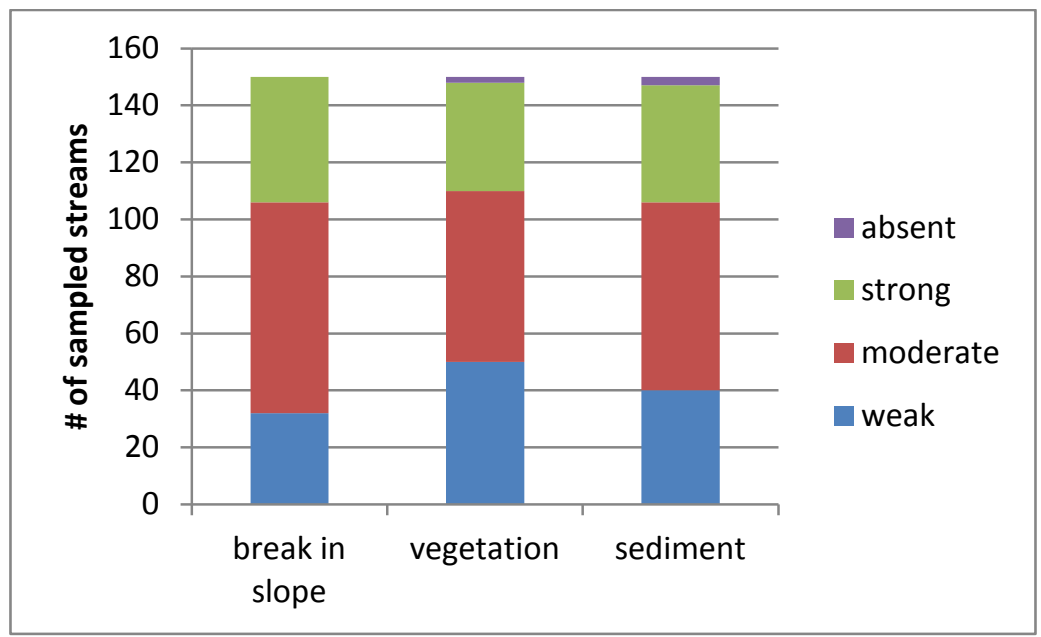


The OHWM was identified by a break in slope in all 150 sampled streams (due to the reliance on macro-scale geomorphic features for identifying the OHWM). At least one of the other two primary indicators was also found in association with the OHWM at each site (i.e., at least two of the three primary indicators were associated with the OHWM at every site), and all three primary indicators were found in association with the OHWM to some degree (i.e., weak, moderate, or strong) at 145 (97\%) of the sites. A change in vegetation characteristics was found in association with the OHWM at 148 (99\%) of the sampled streams, and a change in sediment characteristics was found in association with the OHWM at 147 (98\%) of the sampled streams.

In addition to the three primary indicators described above, a fourth feature (and potential OHWM indicator)—drift deposits-was frequently found throughout the study region. Figure 5 shows the number of sampled streams at which drift deposits were found below, at, and above the OHWM and the total number of sites at which drift deposits were found. Drift was identified at 70 (47\%) of the sampled streams, but at only $9(6 \%)$ of these sites did the location of the observed drift correspond with that of the OHWM. Instead, drift was found below the OHWM at 61(41\%) of the sampled streams and above the OHWM at $42(28 \%)$ of the sampled streams.

Figure 5. The number of sample locations at which drift deposits were found below, at, and above the OHWM. The bar on the right indicates the total number of sampled streams at which drift deposits were found.

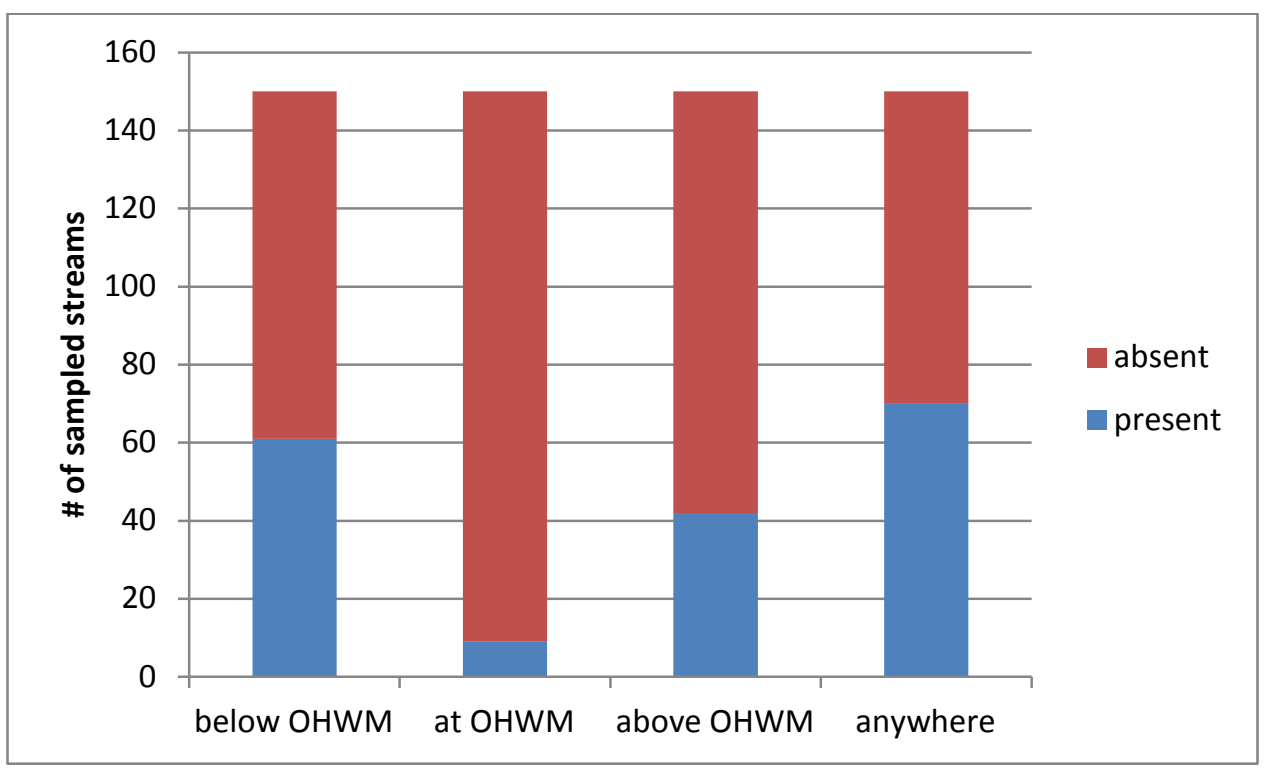




\subsection{Ordination of sampled streams by using watershed and climate variables}

In an ordination of 150 sampled streams based on watershed area, mean watershed elevation, mean annual precipitation, and mean annual SWE, five outliers were identified (Table A1). The outliers exerted extraordinary influence and reduced the explanatory capability of the ordination considerably, so they were removed from the analysis. Figure 6 shows the resulting ordination of 145 sampled streams. Table 3 gives the correlation coefficients of each variable for each of the three axes. Axis 1, which has a strong negative correlation with mean annual SWE $(r=-0.80)$, explains $40.8 \%$ of the variation in the data. Axis 2 , which has moderately strong positive correlations with mean watershed elevation $(r=0.64)$ and mean annual precipitation $(r=0.67)$, explains $32.0 \%$ of the variation in the data. Axis 3 , which has a very strong negative correlation with watershed area $(\mathrm{r}=$ $-0.94)$, explains $23.9 \%$ of the variation in the data. Monte Carlo tests suggested that this solution contained more information than expected by chance $(p=0.0040)$, and stress was low at 7.17.

Figure 6. NMDS ordination of 145 WMVC Region non-perennial streams based on watershed area, mean watershed elevation, mean annual precipitation, and mean annual SWE. Cluster analysis identified five groups in the data, denoted by the different colored points in the

figure. The explanatory capability of each axis (i.e., the percentage of variation in the data that is explained by each axis) is given in the bottom right box. Table 3 gives the correlation coefficients for each variable with each axis.

Axis 3

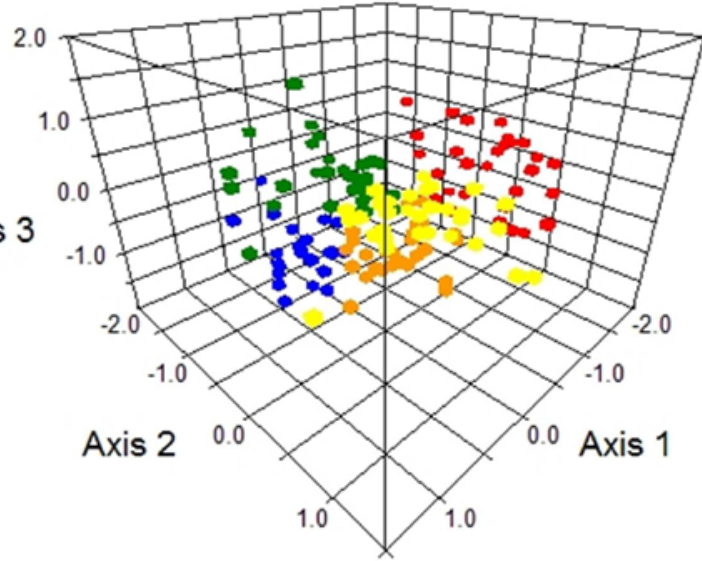

Lowest SWE, largest watersheds - Highest SWE, moderate to small watersheds Moderate SWE, smallest watersheds Low SWE, small watersheds High SWE, large watersheds

Explanatory Capability: Axis 1: $40.8 \%$ Axis 2: $32.0 \%$ Axis $3: 23.9 \%$

Cluster analysis identified five groups in the ordination data (Figure 6), representing a spectrum of stream settings ranging from those draining large watersheds where SWE is low to those draining small watersheds where SWE is high. Discriminant analysis suggested that these five groups 
were significantly different from one another (Wilk's Lambda $=0.65, \mathrm{p}<$ 0.001) and that the cluster analysis was $89 \%$ correct.

Table 3. Correlation coefficients of four variables with each axis in the ordination. These four variables were used to ordinate 145 streams along three axes as shown in Figure 6.

\begin{tabular}{|l|c|c|c|}
\hline \multirow{2}{*}{ Variable } & \multicolumn{3}{|c|}{ Correlation Coefficient } \\
\cline { 2 - 4 } & Axis 1 & Axis 2 & Axis 3 \\
\hline Watershed area & 0.06 & -0.34 & -0.97 \\
\hline $\begin{array}{l}\text { Mean watershed } \\
\text { elevation }\end{array}$ & 0.59 & 0.64 & -0.17 \\
\hline $\begin{array}{l}\text { Mean annual } \\
\text { precipitation }\end{array}$ & -0.67 & 0.67 & 0.10 \\
\hline Mean annual SWE & -0.80 & 0.49 & 0.23 \\
\hline
\end{tabular}

Figure 7 shows the overlay of primary indicator rankings (absent, weak, moderate, or strong) on the ordination for each of the 150 sampled streams (i.e., the coloring of streams by ranking for visual comparison). Table 4 summarizes the rankings of each indicator for each of the five stream groups. Although there is some variability in the distribution of OHWM indicator rankings between the stream groups, no distinct patterns were detected. That is, despite substantial variability between the five stream groups with regard to precipitation and watershed size and elevation, the frequency of occurrence and ranking of the three primary OHWM indicators was fairly consistent across all groups.

Figure 7. Overlay of OHWM primary indicator rankings on an ordination of 145 WMVC Region non-perennial streams. The three primary indicators-break in slope, change in sediment characteristics, and change in vegetation characteristics-are ranked as either absent, weak, moderate, or strong for each stream sampled.
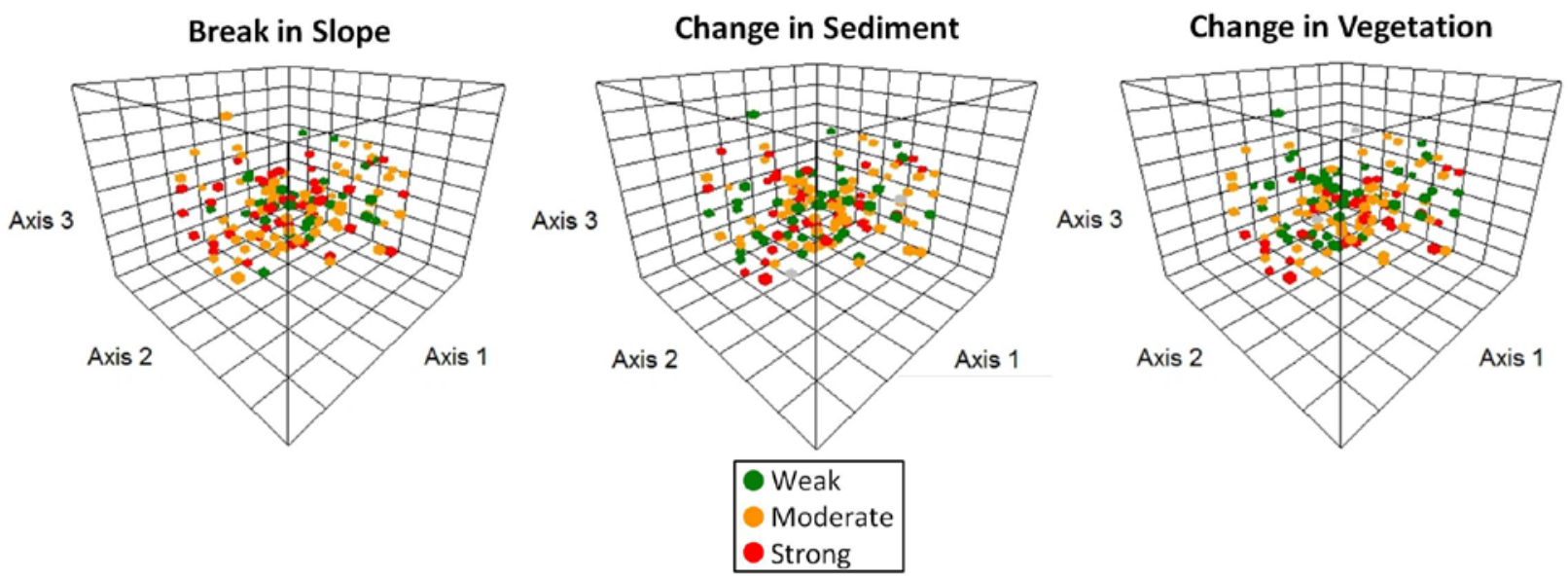
Table 4. Distribution of rankings for the three primary OHWM indicators among the five stream groups identified in an ordination of 145 streams.

\begin{tabular}{|l|c|c|c|c|c|c|c|c|c|c|c|c|}
\hline & \multicolumn{4}{|c|}{ Break in Slope } & \multicolumn{3}{c|}{ Change in Sediment } & \multicolumn{3}{c|}{ Change in Vegetation } \\
\cline { 2 - 14 } & Weak & Mod. & Strong & Total & Weak & Mod. & Strong & Total & Weak & Mod. & Strong & Total \\
\hline $\begin{array}{l}\text { Stream Group (lowest SWE, } \\
\text { largest watersheds) }\end{array}$ & 2 & 12 & 7 & 21 & 6 & 10 & 5 & 21 & 6 & 9 & 6 & 21 \\
\hline $\begin{array}{l}\text { Green (low SWE, } \\
\text { small watersheds) }\end{array}$ & 6 & 15 & 10 & 31 & 9 & 11 & 10 & 30 & 16 & 10 & 5 & 31 \\
\hline $\begin{array}{l}\text { Orange (high SWE, } \\
\text { large watersheds) }\end{array}$ & 8 & 17 & 5 & 30 & 9 & 13 & 7 & 29 & 8 & 13 & 8 & 29 \\
\hline $\begin{array}{l}\text { Yellow (moderate } \\
\text { SWE, smallest } \\
\text { watersheds) }\end{array}$ & 8 & 13 & 12 & 33 & 10 & 16 & 6 & 32 & 10 & 15 & 8 & 33 \\
\hline $\begin{array}{l}\text { Red (highest SWE, } \\
\text { moderate } \\
\text { watersheds) }\end{array}$ & 8 & 16 & 6 & 30 & 6 & 16 & 8 & 30 & 10 & 11 & 8 & 29 \\
\hline Total & $\mathbf{3 2}$ & $\mathbf{7 3}$ & $\mathbf{4 0}$ & $\mathbf{1 4 5}$ & $\mathbf{4 0}$ & $\mathbf{6 6}$ & $\mathbf{3 6}$ & 142 & 50 & $\mathbf{5 8}$ & $\mathbf{3 5}$ & 143 \\
\hline
\end{tabular}

\subsection{Ordination of sampled streams by using channel geometry variables}

A second ordination of 21 sampled streams was based on maximum channel width, maximum channel depth, width-to-depth ratio, and slope (Figure 8); one stream was identified as an outlier (AZ23), but it was retained because it did not reduce the explanatory capability of the ordination. Table 5 gives the correlation coefficients of each variable with each axis. Axis 1 , which has a strong to moderately strong positive correlation with both maximum channel width $(r=0.87)$ and width-to-depth ratio $(\mathrm{r}=0.81)$ and a moderately strong negative correlation with channel slope $(r=-0.74)$, explains $50.6 \%$ of the variation in the data. Axis 2 , which has a strong positive correlation with channel slope $(r=0.90)$ and a strong negative correlation with maximum channel depth $(\mathrm{r}=-0.88)$, explains $46.7 \%$ of the variation in the data. Monte Carlo tests suggested that this solution contained more information than expected by chance $(p=0.01)$, and stress was low at 6.06 . 
Figure 8. NMDS ordination of 21 WMVC Region non-perennial streams by using four channel geometry variables-maximum channel width, maximum channel depth, width-to-depth ratio, and channel slope. The streams were divided into two groups based on cluster analysis. The explanatory capability of each axis (i.e., the percentage of variation in the data that is explained by each axis) is given in the bottom right box.

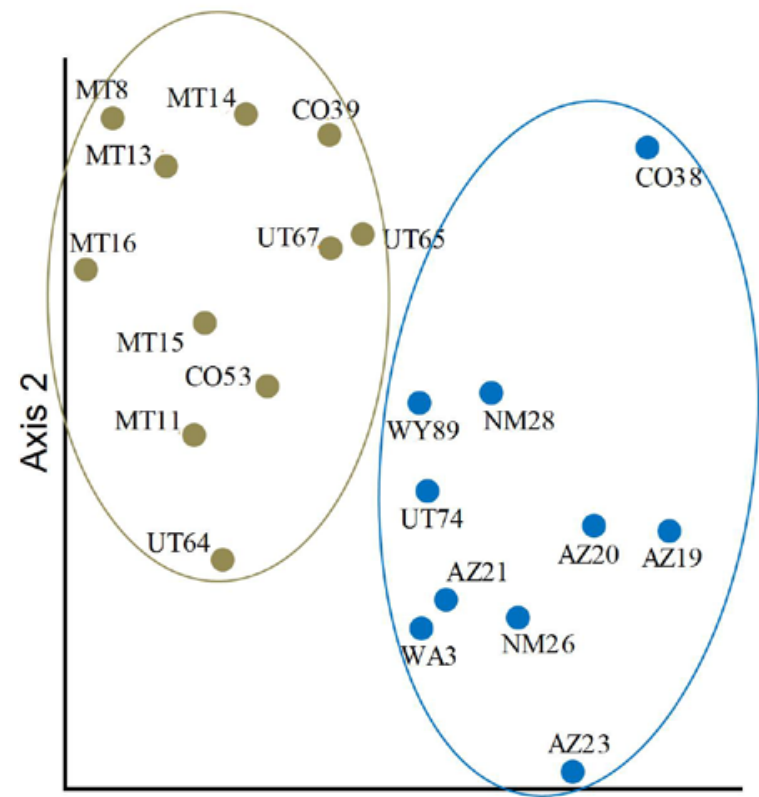

Narrower, shallower, steeper channels Wider, deeper, gradually sloped channels

Explanatory Capability: Axis 1: $50.6 \%$ Axis 2: $46.7 \%$

Axis 1

Table 5. Correlation coefficients of four stream channel variables with each axis in the ordination. These four variables were used to ordinate 21 streams along two axes as shown in Figure 8.

\begin{tabular}{|l|c|c|}
\hline \multirow{2}{*}{ Variable } & \multicolumn{2}{|c|}{ Correlation Coefficient } \\
\cline { 2 - 3 } & Axis 1 & Axis 2 \\
\hline Maximum channel width & 0.87 & -0.70 \\
\hline Maximum channel depth & 0.17 & -0.88 \\
\hline Width-to-depth ratio & -0.81 & 0.08 \\
\hline Channel slope & -0.74 & 0.90 \\
\hline
\end{tabular}

Cluster analysis identified two groups in the ordination data (Figure 8). The first group (delineated with a blue oval in Figure 8 and Figure 9) is dominated by streams in Arizona (AZ) and New Mexico (NM) with relatively wide, deep, and gradually sloped channels. The second group (delineated with a green oval in Figure 8 and Figure 9) is dominated by streams in Montana (MT) and Utah (UT) with relatively narrow, shallow, and steeply sloped channels. Discriminant analyses determined that the two groups were significantly different from one another (Wilk's Lambda $=$ $0.163, \mathrm{p}<0.001)$ and that none of the channels had been misclassified. 
Figure 9 shows the overlay of primary indicator rankings (absent, weak, moderate, or strong) on the ordination for each of the 21 streams sampled for cross-sectional data. Table 6 summarizes the rankings of each indicator for each of the five stream groups. None of the three primary indicators were ranked as absent at any of the 21 stream sites. Although there is some variability in the distribution of OHWM indicator rankings between the two groups, no distinct patterns were detected. That is, despite substantial variability between the two stream groups with regard to location and channel characteristics, the frequency of occurrence and ranking of the three primary OHWM indicators was fairly consistent across both groups.

Figure 9. Overlay of OHWM primary indicator rankings on an ordination of 21 WMVC Region non-perennial streams. The three indicators-break in slope, change in sediment characteristics, and change in vegetation characteristics-are ranked as either absent, weak, moderate, or strong for each stream sampled.
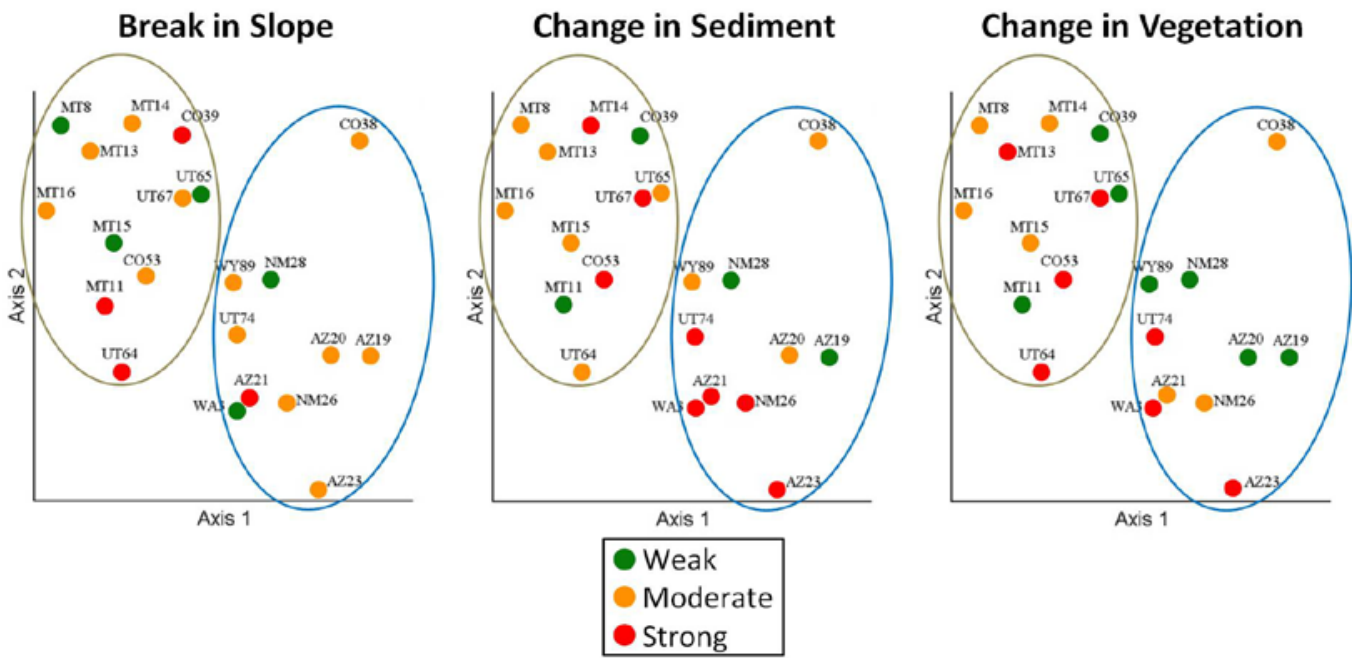

Table 6. Distribution of rankings for the three primary OHWM indicators among the two stream groups identified in an ordination of 21 sampled streams.

\begin{tabular}{|l|c|c|c|c|c|c|c|c|c|c|c|c|}
\hline & \multicolumn{4}{|c|}{ Break in Slope } & \multicolumn{4}{c|}{ Change in Sediment } & \multicolumn{3}{c|}{ Change in Vegetation } \\
\cline { 2 - 15 } & Weak & Mod. & Strong & Total & Weak & Mod. & Strong & Total & Weak & Mod. & Strong & Total \\
\hline $\begin{array}{l}\text { Blue (wide, } \\
\text { deep, gradual } \\
\text { slope) }\end{array}$ & 2 & 7 & 1 & 10 & 2 & 3 & 5 & 10 & 4 & 3 & 3 & 10 \\
\hline $\begin{array}{l}\text { Green (narrow, } \\
\text { shallow, steep) }\end{array}$ & 3 & 5 & 3 & 11 & 2 & 6 & 3 & 11 & 3 & 4 & 4 & 11 \\
\hline Total & $\mathbf{5}$ & $\mathbf{1 2}$ & $\mathbf{4}$ & $\mathbf{2 1}$ & $\mathbf{4}$ & $\mathbf{9}$ & $\mathbf{8}$ & $\mathbf{2 1}$ & $\mathbf{7}$ & $\mathbf{7}$ & $\mathbf{7}$ & $\mathbf{2 1}$ \\
\hline
\end{tabular}




\section{Discussion and Conclusions}

The OHWM is a legal and regulatory concept and boundary with varying interpretations; and as such, there is no way to truly validate the accuracy of an OHWM delineation. Thus, investigations into the OHWM inherently require some assumptions be made regarding both the conceptual basis of the OHWM and the indicators used to identify it. This study generally assumed the OHWM corresponded with the outer limits of the active channel with an emphasis on using macro-scale geomorphic features to delineate the OHWM, based on the reasoning and interpretations discussed in Section 1.1. Additionally, the OHWM approach used here emphasized features evidenced to be stable over time, consistent between different locations, and identifiable by different investigators.

Guided by these criteria and assumptions, three primary indicatorstopographic break in slope, change in sediment characteristics, and change in vegetation characteristics-were consistently found in association with the lateral limits of the active channel, and thus with the OHWM, throughout the WMVC Region. At every site, at least two, but typically all three, of these primary indicators were found in association with the OHWM. In addition to a weak to strong topographic break in slope, the OHWM was also typically characterized by a transition from relatively coarse sediment within the active channel to relatively fine sediment outside of the active channel. Soil development was generally absent within the active channel limits, with varying degrees of soil development outside of the active channel. Additionally, the OHWM was typically characterized by a transition from relatively sparse or young vegetation within the active channel to relatively dense or mature vegetation outside of the active channel.

Regarding changes both in vegetation and sediment characteristics, the location of these changes did not always line up precisely with the edge of the active channel. For instance, vegetation was often found to encroach into the active channel, and sediment texture changes were often found at the edge of the channel bed rather than at the top of the active channel banks (this is likely due, at least in part, to the angle of repose of loose sediments). Still, when considered together, these three indicators typically formed a rather distinct physical and biological signature on the landscape 
associated with the active channel boundaries. This active channel signature, although varying in appearance (depending on local climate, vegetation, etc.), was ubiquitous throughout the WMVC Region.

An important conclusion and recommendation of this study is that, in general, the OHWM in WMVC non-perennial streams should be identified and delineated using at least two primary indicators. This is because individual primary indicators are also commonly found above or below the OHWM. Multiple breaks in slope may be found along a given stream transect, for instance. An examination of vegetation and sediment characteristics, however, can help to narrow down which break in slope is most likely associated with the active channel boundaries and thus with the OHWM. Likewise, multiple changes in sediment or vegetation characteristics are common along a given cross-section of a stream system. Hence, when used individually and without consideration of other indicators, primary indicators can also be highly misleading with respect to identifying the OHWM.

Despite substantial variability in location, climate, and watershed and channel characteristics among the 150 sampled streams, the active channel limits, and thus the OHWM, were consistently associated with the same three primary indicators throughout the WMVC Region. The absence of any distinct patterns or relationships with respect to the distribution of OHWM indicators throughout the region is suggestive of the robust nature of the active channel signature and the primary indicators that compose it.

A fourth potential OHWM indicator, drift, was found throughout the WMVC Region but rarely in conjunction with the three primary indicators. This suggests that drift deposits are unreliable OHWM indicators in WMVC Region non-perennial streams. That drift deposits proved unreliable is not surprising given that they are typically the remnants of single flow events and can thus shift frequently in time and space. Therefore, while these features may give an indication of the extent of particular flow events, they do not generally represent ordinary high flow conditions at a given location. This reasoning can be applied to a variety of other features, such as litter and leaf removal, mud cracks, matted vegetation, and other similar indicators of recent or single flow events. These features may help to interpret recent flow conditions at a site but should not be relied on to pinpoint the precise location of the OHWM. Note that these findings do not apply to marine or lacustrine environments in which drift and other similar features may be useful OHWM indicators. 
Practical limitations with regard to sampling did not allow for in-depth assessment of the temporal variability of OHWM indicators. Future studies should include repeat sampling of OHWM indicators to better understand their stability over time. Repeat sampling in different seasons would allow for assessment of seasonal variability in the appearance of OHWM indicators. Additionally, future studies could examine how the findings of this study apply to perennial streams and to other regions. Finally, future studies could attempt to quantify primary indicators and other supporting features to a greater extent for more in-depth analysis. These limitations aside, this study has provided useful information that may help to improve OHWM delineation practices in the WMVC Region and potentially elsewhere. 


\section{References}

Bailey, R. G. 1995. Description of the ecoregions of the United States. 2nd ed. Miscellaneous Publication 1391 (revised). Washington, DC: U.S. Department of Agriculture, Forest Service. http://www.fs.fed.us/land/ecosysmgmt/ecoreg1_home.html.

Curtis, K. E., R. W. Lichvar, and L. Dixon. 2011. Ordinary High Flows and the StageDischarge Relationship in the Arid West Region. ERDC/CRREL TR-11-12. Hanover, NH: U.S. Army Engineer Research and Development Center.

Guest, D. 1990. The Ordinary High Water Boundary on Freshwater Lakes and Streams: Origin, Theory, and Constitutional Restrictions. J ournal of Land Use and Environmental Law 6 (2): 205-240.

Lefebvre, L., R. Lichvar, and K. Curtis. 2013a. Survey of OHWM Indicator Distribution Patterns Across Arid West Landscapes. ERDC/ CRREL TR-13-2. Hanover, NH: U.S. Army Engineer Research and Development Center.

Lefebvre, L., R. Lichvar, K. Curtis, and J . Gillrich. 2013b. Channel Classification Across Arid West Landscapes in Support of OHW Delineation. ERDC/ CRREL TR-13-3. Hanover, NH: U.S. Army Engineer Research and Development Center.

Lichvar, R. W., and J . S. Wakeley. 2004. Review of Ordinary High Water Mark Indicators for Delineating Arid Streams in the Southwestern United States. ERDC TR-04-1. Hanover, NH: U.S. Army Engineer Research and Development Center.

Lichvar, R. W., D. C. Finnegan, M. P. Ericsson, and W. Ochs. 2006. Distribution of Ordinary High Water Mark (OHWM) Indicators and Their Reliability in Identifying the Limits of "Waters of the United States" in Arid Southwestern Channels. ERDC/CRREL TR-06-5. Hanover, NH: U.S. Army Engineer Research and Development Center.

Lichvar, R. W., and S. M. McColley. 2008. A Field Guide to the Identification of the Ordinary High Water Mark (OHWM) in the Arid West Region of the Western United States. ERDC/ CRREL TR-08-12. Hanover, NH: U.S. Army Engineer Research and Development Center.

Lichvar, R. W., D. Cate, C. Photos, L. Dixon, B. Allen, and J . Byersdorfer. 2009. Vegetation and Channel Morphology Responses to Ordinary High Water Mark Discharge Events in Arid West Stream Channels. ERDC/ CRREL TR-09-5. Hanover, NH: U.S. Army Engineer Research and Development Center.

MoCune, B., and J . B. Grace. 2002. Analysis of Ecological Communities. Gleneden Beach, OR: MjM Software Design.

McCune, B., and M. J . Mefford. 2006. PC-ORD. Multivariate Analysis of Ecological Data. Version 5.33. Gleneden Beach, OR: MjM Software Design. 
U.S. Army Corps of Engineers. 2005. Ordinary High Water Mark Identification. Regulatory Guidance Letter 05-05. Washington, DC: U.S. Army Corps of Engineers.

U.S. Army Corps of Engineers. 2010. Regional Supplement to the Corps of Engineers Wetland Delineation Manual: Western Mountains Valleys, and Coast Region (Version 2.0), ed. J. S. Wakeley, R. W. Lichvar, and C. V. Noble. ERDC/ EL TR10-3. Vicksburg, MS: U.S. Army Engineer Research and Development Center.

U.S. Army Corps of Engineers. 2012. 2012 Nationwide Permits, Conditions, District Engineer's Decision, Further Information, and Definitions (with corrections). http://www.usace.army.mil/Portals/2/docs/civilworks/nwp/2012/NWP2012_corrections_21sep-2012.pdf.

U.S. Congress. 1977. Clean Water Act. Codified at 33 U.S.C. 1251 (et seq.). Washington, DC: U.S. Government Printing Office.

U.S. Congress. 1986. Definition of "Waters of the United States." Codified at 33 CFR 328.3 (et seq.). Washington, DC: U.S. Government Printing Office.

USDA Natural Resources Conservation Service. 2006. Land resource regions and major land resource areas of the United States, the Caribbean, and the Pacific Basin. Agriculture Handbook 296. Washington, DC: U. S. Department of Agriculture. (http:// soils.usda.gov/ survey/geography/mlra/ index.html)

Wolman, M. G., and J. P. Miller. 1960. Magnitude and Frequency of Forces in Geomorphic Processes. The J ournal of Geology 68 (1): 54- 74. doi:10.2307/ 30058255. 


\section{Appendix A: Study Site Locations}

Table A1. County locations of the 150 stream sites sampled for this study.

\begin{tabular}{|c|c|c|c|}
\hline Site & Location & Site & Location \\
\hline $\mathrm{AZ19}^{*}$ & Coconino County, AZ & C054 & Rio Blanco County, CO \\
\hline AZ20* & Coconino County, AZ & C055 & Routt/Rio Blanco County, CO \\
\hline$A Z 21^{*}$ & Coconino County, AZ & C056 & Boulder County, CO \\
\hline AZ22 & Coconino County, AZ & $\operatorname{co57}$ & Larimer County, CO \\
\hline$A Z 23^{*} \ddagger$ & Coconino County, AZ & C058 & Larimer County, CO \\
\hline CA125 & Kern County, CA & $\operatorname{co59}$ & Larimer County, CO \\
\hline CA126 & Tulare County, CA & $\mathrm{CO60}$ & Boulder County, CO \\
\hline CA127 & Tulare County, CA & C061 & Jackson County, CO \\
\hline CA128 & Tulare County, CA & C063 & La Plata County, CO \\
\hline $\mathrm{CA}^{2} 30^{\dagger}$ & Tulare County, CA & C065 & La Plata County, CO \\
\hline $\mathrm{CA}^{2} 2^{\dagger}$ & Madera County, CA & C066 & Chaffee County, CO \\
\hline CA134 & Alpine County, CA & C067 & Chaffee County, CO \\
\hline CA135 & Alpine County, CA & C068 & Mineral County, CO \\
\hline CA136 & Placer County, CA & $\mathrm{CO} 70$ & Mineral County, CO \\
\hline CA137 & Sierra County, CA & CO71 & Archuleta County, CO \\
\hline CA138 & Plumas/Sierra County, CA & $\mathrm{CO} 72$ & Mineral County, CO \\
\hline CA139 & Plumas County, CA & $\mathrm{CO73}$ & Archuleta County, CO \\
\hline $\mathrm{CA142}^{\dagger}$ & Shasta County, CA & CO74 & Archuleta County, CO \\
\hline CA151 & Tulare County, CA & IDO & Boundary County, ID \\
\hline C034 & Gunnison County, CO & ID4 & Boundary County, ID \\
\hline C035 & Gunnison County, CO & ID76 & Franklin County, ID \\
\hline C036 & Gunnison County, CO & ID77 & Franklin County, ID \\
\hline C037 & Chaffee County, CO & ID78 & Franklin County, ID \\
\hline $\mathrm{CO}^{*}{ }^{*}$ & Chaffee County, CO & ID92 & Fremont County, ID \\
\hline $\mathrm{CO39}^{*}$ & Chaffee County, CO & ID93 & Fremont County, ID \\
\hline $\mathrm{CO40}$ & Gunnison County, CO & ID95 & Lemhi County, ID \\
\hline $\mathrm{CO41}$ & Ouray County, CO & ID96 & Lemhi County, ID \\
\hline $\mathrm{CO42}$ & Montrose County, CO & ID97 & Lemhi County, ID \\
\hline $\mathrm{CO44}$ & Delta County, CO & ID98 & Lemhi County, ID \\
\hline CO45 & Delta County, CO & ID99 & Lemhi County, ID \\
\hline CO46 & Mesa County, CO & ID100 & Lemhi County, ID \\
\hline $\mathrm{CO47}$ & Mesa County, CO & ID102 & Lemhi County, ID \\
\hline
\end{tabular}




\begin{tabular}{|c|c|c|c|}
\hline Site & Location & Site & Location \\
\hline $\mathrm{co48}$ & Mesa County, CO & ID103 & Custer County, ID \\
\hline CO49 & Mesa County, CO & ID104 & Custer County, ID \\
\hline $\mathrm{CO50}$ & Delta County, CO & ID105 & Custer County, ID \\
\hline C051 & Garfield County, CO & ID106 & Custer County, ID \\
\hline C052 & Rio Blanco County, CO & ID107 & Custer County, ID \\
\hline $\mathrm{CO53}^{*}$ & Rio Blanco/Garfield & ID109 & Blaine County, ID \\
\hline ID110 & Custer County, ID & UT8 & Sevier County, UT \\
\hline ID111 & Boise County, ID & UT9 & Sevier County, UT \\
\hline MT5 & Lincoln County, NM & UT10 & Sanpete County, UT \\
\hline MT6 & Glacier County, MT & UT12 & Utah County, UT \\
\hline MT7 & Flathead County, MT & UT16 & Wasatch County, UT \\
\hline MT8* & Flathead County, MT & UT62 & Utah County, UT \\
\hline MT10.2 & Mineral County, MT & UT63 & Wasatch County, UT \\
\hline MT11 $^{*}$ & Mineral County, MT & UT64* & Wasatch County, UT \\
\hline MT12.1 & Mineral County, MT & UT65* & Summit County, UT \\
\hline MT12.2 & Mineral County, MT & UT66 & Summit County, UT \\
\hline MT12.3 & Mineral County, MT & UT67* & Daggett County, UT \\
\hline MT13* $^{*}$ & Mineral County, MT & UT68 & Uintah County, UT \\
\hline MT14 $^{*}$ & Missoula County, MT & UT69 & Salt Lake County, UT \\
\hline MT15* & Powell County, MT & UT70 & Weber County, UT \\
\hline MT16* & Powell/Missoula County, MT & UT72 & Cache County, UT \\
\hline MT66† & Glacier County, MT & UT73 & Cache County, UT \\
\hline NM6 & Santa Fe County, NM & UT74* & Cache County, UT \\
\hline NM7 & Santa Fe County, NM & WA1 ${ }^{\dagger}$ & Skagit County, WA \\
\hline NM24 & Grant County, NM & WA2 & Okanogan County, WA \\
\hline NM25 & Grant County, NM & WA3.1 & Ferry County, WA \\
\hline NM26* & Grant County, NM & WA3* & Ferry County, WA \\
\hline NM27 & Catron/Sierra County, NM & WY80 & Lincoln County, WY \\
\hline NM28* & Catron County, NM & WY81 & Lincoln County, WY \\
\hline NM30 & Torrance County, NM & WY82 & Lincoln County, WY \\
\hline NM31 & Torrance County, NM & WY84 & Teton County, WY \\
\hline OR144 & Klamath County, OR & WY85 & Sublette/Teton County, WY \\
\hline OR145 & Crook County, OR & WY86 & Sublette County, WY \\
\hline OR146 & Crook County, OR & WY87 & Sublette County, WY \\
\hline OR148 & Grant County, OR & WY88 & Fremont County, WY \\
\hline OR150 & Clackamas County, OR & WY89* & Fremont County, WY \\
\hline UT1 & Washington County, UT & WY90 & Fremont County, WY \\
\hline
\end{tabular}




\begin{tabular}{|l|l|c|l|}
\hline \multicolumn{1}{|c|}{ Site } & \multicolumn{1}{c|}{ Location } & Site & \multicolumn{1}{c|}{ Location } \\
\hline UT2 & Washington County, UT & WY115 & Teton County, WY \\
\hline UT3 & Iron County, UT & WY116 & Teton County, WY \\
\hline UT4 & Iron County, UT & WY119 & Park County, WY \\
\hline UT5 & Iron County, UT & WY120 & Park County, WY \\
\hline UT6 & Kane County, UT & WY121 & Park County, WY \\
\hline UT7 & Garfield County, UT & WY123 & Park County, WY \\
\hline
\end{tabular}

* Site at which cross sections were taken

† Site determined to be an outlier in the analysis, based on watershed and climate variables

₹ Site determined to be an outlier in the analysis, based on channel geometry variables 


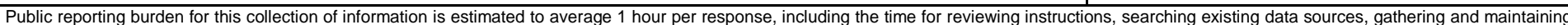

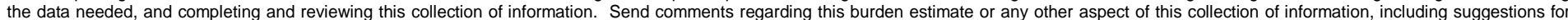

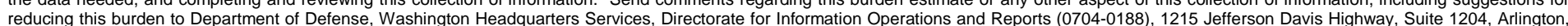

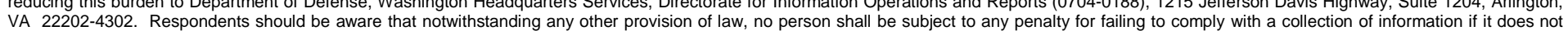
VA 22202-4302. Respondents should be aware that notwithstanding any other provision of law, no person shall be sube
display a currently valid OMB control number. PLEASE DO NOT RETURN YOUR FORM TO THE ABOVE ADDRESS.
1. REPORT DATE (DD-MM-YYYY) 2. REPORT TYPE
August 2014
Technical Report/ Final

\section{TITLE AND SUBTITLE}

Occurrence and Distribution of Ordinary High Water Mark (OHWM) Indicators in Non-Perennial Streams in the Western Mountains, Valleys, and Coast Region of the United States

3. DATES COVERED (From - To)

5a. CONTRACT NUMBER

5b. GRANT NUMBER

5c. PROGRAM ELEMENT NUMBER

5d. PROJECT NUMBER

6. AUTHOR(S)

Matthew K. Mersel, Robert W. Lichvar, J ennifer J . Gillrich, and Lindsey E. Lefebvre

\section{PERFORMING ORGANIZATION NAME(S) AND ADDRESS(ES)}

U.S. Army Engineer Research and Development Center

Cold Regions Research and Engineering Laboratory

72 Lyme Road

Hanover, NH 03755-1290

\section{SPONSORING / MONITORING AGENCY NAME(S) AND ADDRESS(ES)}

Wetlands Regulatory Assistance Program (WRAP)

U.S. Army Corps of Engineers

Vicksburg, MS 39180-6133

\section{DISTRIBUTION I AVAILABILITY STATEMENT}

Approved for public release; distribution is unlimited.

\section{SUPPLEMENTARY NOTES}

\section{ABSTRACT}

This study explored the occurrence and distribution of ordinary high water mark (OHWM) indicators in non-perennial streams in the Western Mountains, Valleys, and Coast (WMVC) Region of the United States. Physical and biological indicators of the OHWM were recorded and ranked (weak, moderate, or strong) at 150 ephemeral or intermittent stream sites sampled across the region. Three primary OHWM indicators-topographic break in slope, change in sediment characteristics, and change in vegetation characteristics-were found to be ubiquitous throughout the WMVC Region. At each stream sampled, a combination of at least two of these primary indicators was found to express a signature on the landscape, generally consistent with the lateral boundaries of the active channel. The distribution of the primary indicators and their rankings within the region showed no relationships to various climate, watershed, or channel characteristics examined using multivariate statistical analysis. This suggests the robust nature of these primary indicators and the active channel signature for delineating the OHWM in non-perennial streams throughout the WMVC Region. These findings support a more informed and consistent approach to OHWM delineation in the WMVC Region.

\begin{tabular}{|c|c|c|c|c|c|}
\hline \multicolumn{2}{|c|}{$\begin{array}{l}\text { 15. SUBJECT TERMS } \\
\text { Delineation } \\
\text { Indicators }\end{array}$} & $\begin{array}{l}\text { Non-perennia } \\
\text { OHWM } \\
\text { Ordinary high }\end{array}$ & er mark & \multicolumn{2}{|c|}{ Western mountains } \\
\hline \multicolumn{3}{|c|}{ 16. SECURITY CLASSIFICATION OF: } & \multirow[t]{2}{*}{$\begin{array}{l}\text { 17. LIMITATION } \\
\text { OF ABSTRACT }\end{array}$} & \multirow[t]{2}{*}{$\begin{array}{l}\text { 18. NUMBER } \\
\text { OF PAGES }\end{array}$} & $\begin{array}{l}\text { 19a. NAME OF RESPONSIBLE } \\
\text { PERSON }\end{array}$ \\
\hline $\begin{array}{c}\text { a. REPORT } \\
\mathrm{U}\end{array}$ & $\begin{array}{c}\text { b. ABSTRACT } \\
U\end{array}$ & $\begin{array}{c}\text { c. THIS PAGE } \\
\text { U }\end{array}$ & & & $\begin{array}{l}\text { 19b. TELEPHONE NUMBER (include } \\
\text { area code) }\end{array}$ \\
\hline
\end{tabular}

